\title{
Use of Innofreight Containers for Thermal Coal Transportation
}

\author{
Václav Cempírek ${ }^{1}$, Jaromír Široký, ${ }^{2,}$, Petr Nachtigall $^{2}$, and Pavlína Hlavsová ${ }^{2}$ \\ ${ }^{1}$ College of Logistics, Přerov, Palackého 1381/25, 75002 Přerov, Czech Republic \\ ${ }^{2}$ University of Pardubice, Faculty of Transport Engineering, 53210 Pardubice, Czech Republic
}

\begin{abstract}
The article discusses the change of siding technology for a fossil fuel power plant using a new reloading system of Innofreight containers. This is a modern system for transporting thermal coal in special transport units - Innofreight containers. The assessment of the new technology takes into account not only technical, but above all technological and economic changes and benefits. There was an analysis of the current situation and it was decided to introduce the new technology of Innofreight system. Its implementation brought additional investment in treatment of industrial tracks for loading, the construction of transshipment facilities for containers, CCTV installation, and a higher degree of security equipment.
\end{abstract}

\section{Introduction}

The transportation of thermal coal for thermal power plants is currently provided by unit trains composed of four-axle bogie open hopper cars of the Falls type. The unloading of the cargo takes place in a special unloading hopper by opening the side flaps of the different groups of Falls railcars in either of the two ways [1]:

- manually, by operating the levers of the side flaps from the front platform of the car, or - automatically, using pneumatic control.

The change of the transportation technology is due to the outdating of Falls railroad cars, which are nearing the end of their service life. For this reason, innovative ways of transporting thermal coal are sought, and the Innofreight container system is one of them.

Thermal coal is loaded into inland Innofreight containers on railroad cars of the Sggrrs series. Every two four-axle bogie cars are connected by a rigid coupling to form an articulated car. The weight of the articulated car is 42.70 tons, the loading weight for the D2 line category (22.5 tons per axle; 6.4 tons per running meter of the car) is 128.2 tons and for the D3/D4 line category (22.5 tons per axle) it is 137.3 tons, the total length of the car over the bumpers is 26.71 meters, the height of the loading area above the top of the rail is 1155 $\mathrm{mm}[2]$.

The unloading of coal is carried out using a special tippler, which includes handling skids to gradually remove the individual containers from the railroad cars in a horizontal direction, followed by a $180^{\circ}$ rotation to unload them. The unloaded coal is transported by

*Corresponding author: jaromir.siroky@upce.cz 
belt conveyors to a storage site and then to a landfill. When introducing the new Innofreight technology, initial investments must be anticipated, both in the Innofreight technology itself and also in the construction and technical adjustments of the siding [3].

\section{Technological changes with the introduction of the new Innofreight system}

This section describes the current unloading technology of the Falls cars and the new technology of unloading cars with Innofreight containers. The assessment is performed with an emphasis on the technological evaluation of both processes.

\subsection{Technological procedures in coal transportation using Falls cars}

The siding of the power plant is composed of one shunting circuit. The shunting itself is performed by the head of the shunting crew. The head of the shunting crew must request for a permission to shunt from the dispatcher orally, by public address system, or radio station.

The manually built sets of switches are operated by the head of the shunting crew alone. Centrally built set of switches are operated by dispatchers from the signal box [4].

The head of the shunting crew is responsible for correctly performing the selected procedure when moving the cars on the deep coal storage site, following the operational solution upon agreement with the coal feeding professional and with the dispatcher on shift. Moving the cars on the deep coal storage site may be performed only by shunting.

Table 1. Technological time of terminating train processing. Source: authors

\begin{tabular}{|c|c|c|}
\hline Task & $\begin{array}{c}\text { Duration } \\
\text { [min] }\end{array}$ & Technological time \\
\hline 1. securing the train & 2 & \\
\hline 2. separation of the drive unit & 5 & \\
\hline 3. receipt of train documentation & 2 & \\
\hline $\begin{array}{l}\text { 4. technical inspection - } 32 \text { cars ( } 16 \text { car units), } 1.2 \\
\mathrm{~min} / \mathrm{car}+\text { walk }\end{array}$ & 38,4 & \\
\hline $\begin{array}{l}\text { 5. transportation inspection - the same applies } \\
\text { (concurrent) }\end{array}$ & 38,4 & \\
\hline 6. notice on termination & 2 & \\
\hline Total processing time & & $49,4 \mathrm{~min}$ \\
\hline
\end{tabular}

The technological processing of a terminating train is shown in Table. 1. The tasks related to the operation of a terminating train are indicated as follows [5]:

1. securing the train,

2. separation of the drive unit,

3. receipt of train documentation,

4. technical inspection,

5. transportation inspection (concurrent with the technical inspection),

6. notice on the termination of processing.

The total processing time of a terminating train is set at 49.4 minutes (see Table 1). The terminating train of the Innofreight set of cars will be processed in a similar manner. This new technology does not have a significant influence on the technological time of processing the terminating train.

The head of the shunting crew is responsible for proper cleaning of the cars and checking them, for proper coupling of the cars into the train, which are reported as ready to be shunted. The cleaning is performed by employees of the power plant. Together with the 
dispatcher, they are responsible for correct and proper train composition and decommissioning cars with a technical defect [6].

The unloading of thermal coal from the cars is performed on the deep coal storage site in either of the two ways, by manually-operated levers, or automatically using pneumatic operation of the side flaps. Unloading using manual opening of the side flaps is carried out from the car platform. The pneumatic way of unloading coal is performed by compressed air from the central distribution system. Final cleaning of the cars is done by the operator using compressed air also from the central distribution system. In winter when the temperatures are below zero and the coal starts freezing up, a defrosting tunnel with a maximum capacity set for 16 cars is used. The supply and regulation of hot air into the tunnel is controlled from the boiler room, including the operation and setting the output of the main and booster fan.

After the head of the shunting crew shunts and hands over the cars to the unloading personnel, the unloading begins. After unloading the cars, cleaning coal residues, closing the cars, securing the side flaps and cleaning the unloading tracks, the unloading personnel hands the cars over back to the head of the shunting crew. The handover of cars between the unloading personnel and the head of the shunting crew proceeds by means of verbal commands.

\subsection{Technological processes during coal transportation in Innofreight containers}

The unloading equipment for Innofreight containers must be placed at the unloading handling track. The construction changes require the extension of the handling tracks, which would allow shunting the shunting unit, without restricting the occupancy of running tracks intended for the entry of trains. The shunt will be controlled from the signal box, which will now be placed in close proximity to the Innofreight tippler. This modification will result in the centralization of traffic control on the siding from a single place and will also lead to a greater availability of personnel during reloading the cars with Innofreight containers. Similarly to the existing technology, the train with Innofreight containers will be split into 2 parts with 8 cars each (16 Innofreight containers). The new organization of the shunt requires a modernization of the shunt locomotive and modification for remote control operation, which would produce a saving on the operating personnel (the shunter in particular), as the engine driver will have control over the whole shunting unit, which will not be operated from their footplate.

The reloading of coal by the Innofreight unloading equipment is important in terms of time demands. Unit time for reloading 1 container is 2.5 minutes. The technological chart of the operation of the Innofreight set of cars is shown in Table 2. With regard to the division of the train into two parts, the technological time necessary for operating the remote control is also taken into account and there is also an increase in the time necessary for shunting out and docking with the given group of cars. However, these times do not play a significant role with respect to the total time of unloading one train of Innofreight cars, which is 195 minutes.

Using this method of unloading coal, there is a twofold occupancy of the lead track when shunting the shunting unit on the entering lead track, which may especially in peak demand (supply of thermal coal) have negative effect on the arrival or departure of other trains. 
Table 2. Technological chart of unloading the train (split into two parts). Source: authors

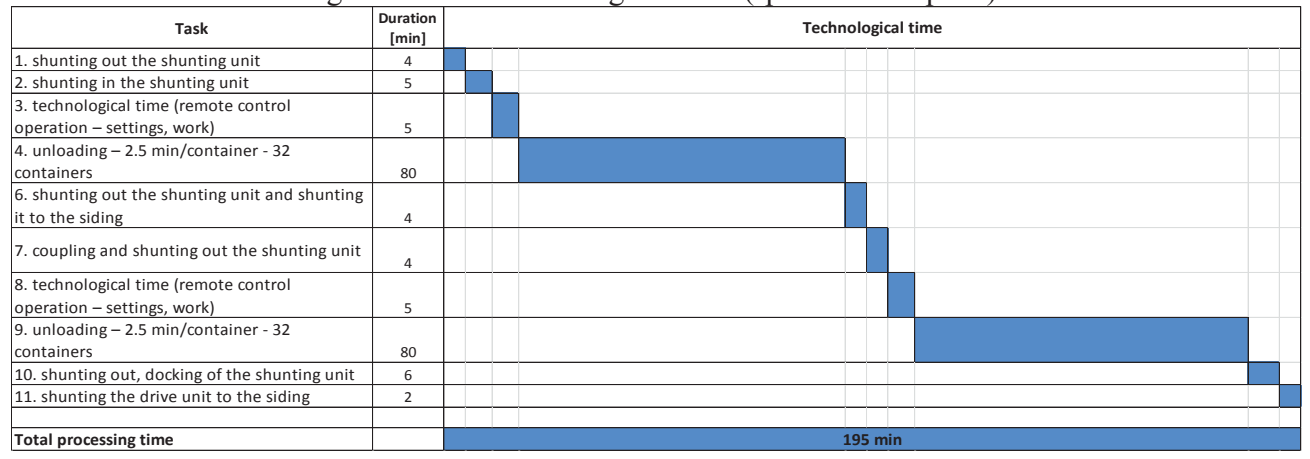

It is important to bear in mind that especially at the beginning of the operation of this system time reserve needs to be allowed for (due to the lack of experience of the operating personnel). Therefore, the estimated total reloading time of one train may be up to 4 hours.

Table 3. Technological chart of unloading the train (at once). Source: authors

\begin{tabular}{|c|c|c|}
\hline Task & $\begin{array}{c}\text { Duration } \\
\text { [min] }\end{array}$ & Technologický čas \\
\hline 1. shunting out the shunting unit & 4 & \\
\hline 2. shunting in the shunting unit & 5 & \\
\hline $\begin{array}{l}\text { 3. technological time (remote control } \\
\text { operation - settings, work) }\end{array}$ & 5 & \\
\hline 4. unloading $-2.5 \mathrm{~min} /$ container -64 container: & 160 & \\
\hline 5. shunting out, docking of the shunting unit & 6 & \\
\hline 6. shunting the drive unit to the siding & 2 & \\
\hline Total processing time & & $182 \mathrm{~min}$ \\
\hline
\end{tabular}

After the track adjustment, it will be possible to unload the whole train at once, without the need for disconnecting the train and further handling. The technological chart will become simpler, as shown in Table 3. This measure will shorten the unloading time by approximately 13 minutes to 182 minutes. In addition, the time of occupying the entering lead track will also be shorter and tasks associated with splitting one train into two shunting units will not need to be performed. This change of technology will produce a saving of workforce necessary for this task.

Similarly to the existing technology of unloading coal from the Falls cars, the same time demands may be assumed for performing a technical inspection (1 hour) and for a technical inspection and testing brakes after the completion of unloading ( 2 hours).

The total time required for reloading cars with Innofreight containers is approximately $6.5-$ 7 hours [7].

\section{Logistics system}

The future of the transportation of goods lies in flexibility, speed and ecology. These requirements are fully addressed by the new Innofreight container system, characterized by high degree of flexibility and efficient logistics solution for rail transportation of bulk goods.

Special dump containers of various types are used in combination with an innovative way of unloading them using reloaders with rotary handling systems.

The Innofreight container system is suitable for the transportation of bulk commodities in agriculture, chemical industry, extractive industry, or waste management. 
The weight of the MonTainer XXL container designed for thermal coal transportation is 3.4 tons, with a loading weight of 38 tons and loading volume of $38 \mathrm{~m} 3$. The container is intended for loose materials with high specific weight and is constructed for maximum useful load and heavy-duty use [8].

Mobile handling equipment with reloading in the horizontal direction is represented by a reloader with a rotary device equipped with a sensor for measuring the weight of unloaded goods with a dumping capacity of $600 \mathrm{~m}^{3} / \mathrm{h}$.

A stationary unloader is used for fast and efficient horizontal unloading. This system is optimal for unloading large volumes of material, or when the handling area for unloaded goods is limited.

The conducted expert study on the change of transportation technology and supply of thermal coal in Innofreight containers concludes that with the annual transportation volume of 2 million tons of coal, the new system will due to its higher loading weight require 129 less unit trains than the current system, i.e. trains composed of Falls cars. The lower number of trains will save 8.8 mil. CZK annually in rail network usage. The calculation is based on the information on the train route from the IS KADR (Route Capacity information system). This substantial saving does not include the discount for combined transport, which is according to the Statetement on the railway system 2017 document $40 \%$ [9]. With this saving in rail networks usage, the annual saving would increase by 25.4 million CZK to 34.2 million CZK.

The system using MonTainer XXL containers for the transportation of thermal coal is $13 \%$ more efficient in comparison with the currently used Falls cars.

Voestalpine Stahl company in Donawitz, Austria uses containers of the MonTainer XXL type for the transportation of coke. Compared to standard railroad freight cars, these containers have a $30 \%$ higher loading weight per unit train.

The Innofreight system is $9-13 \%$ more efficient compared to modern freight cars of the Falls type, which have a loading weight of 66.0 or 69.7 tons. The containers are unloaded by one person only.

\section{Conclusion}

The assessed plan of change in technology includes an independent recommendation that introduces the latest transportation technology for transporting thermal coal. Lowmaintenance technological equipment and elimination of the influence of weather conditions combined with low staffing requirements ensures a continuous supply of thermal coal in accordance with the requirements of the end customer (within the agreed time frame).

The new technology requires modifications of the signaling systems, unloading systems, siding tracks and technological procedures, which are necessary not only with regard to the introduction of a new, modern transportation technology, but also with regard to the technical obsolescence of the siding systems. These investment costs have a payback period of maximum 10 years, as the annual saving in rail network usage is around 8.8 million of CZK. The authors conclude that without the proposed investment adjustments it is not feasible to operate the Innofreight system.

This paper is supported by the research project "From horse-drawn railway to intermodal transport" within Visegrad Fund. 


\section{References}

1. J. Široký, et al., Transport Technology and Control (Tribun EU, Brno, Czech Republic, 2014)

2. J. Novák, V. Cempírek, I. Novák, J. Široký, Intermodal Transport (University of Pardubice, Czech Republic, 2015)

3. J. Jagelčák, A. Dávid, P. Rožek, Sea Containers (EDIS: University of Zilina, Slovak Republic, 2010)

4. S. Bahri, Y. Huseyin, U. Yasin, A. Guneri, G. Bahadir, E. Turan, The Scientific World Journal 2014 (2014), DOI: 10.1155/2014/630320

5. Y.M. Bontekoning, C. Macharis, J.J. Trip, Transportation Research Part A: Policy and Practice 38, 1-34 (2014)

6. C. Macharis, Y.M. Bontekoning, European Journal of Operational Research 153, 400416 (2004)

7. Intermodal terminals. Intermodal terminals in Europe, Available online: http://www.intermodal-terminals.eu/database/terminal/view/id/127 (2013)

8. Multimodal Transport Systems, CVUT Transport Faculty, Available online: http://www.fd.cvut.cz/projects/k612x1mp/vn.html (2014)

9. Railway Infrastructure Administration, Statement on national and regional railway, Available online: http://www.szdc.cz (2017) 